\title{
Educational Mismatch between Graduate Possessed Knowledge and Market Demands
}

\author{
Dr. Muhammad Uzair-ul-Hassan \\ Assistant Professor, Department of Education, University of Sargodha \\ Email: uhassan74@yahoo.com
}

Zahida Noreen

Research scholar, Department of Education, University of Sargodha

\author{
Doi:10.5901/ajis.2013.v2n3p191
}

\section{Abstract}

In today's world knowledge is considered as an engine of economy of a country. Any mismatch in knowledge that graduates possess and market requires would not make the economy more effective. This study was conducted to find out the educational mismatch between graduates possessed knowledge and market demands. Convenient sampling was carried out and data were collected from 200 graduates of economics. Further, 32 employers of various organizations were also included from whom requisite knowledge in market was investigated. The statistical techniques t-test and percentage of responses were employed to analyze the data. Analysis shows that there exists difference between knowledge possessed by graduates of economics and knowledge demanded by the employers. It was also found out that there was a significant difference between knowledge possessed by male and female, and high and low achiever graduates in economics. Whereas, no significant difference exists in knowledge possessed by graduates who are in jobs either full-time or part-time. It was concluded that knowledge of interconnection between economic and other phenomena, marginal considerations and impact of expectations and surprises are main causes of educational mismatch.

\section{Background}

The term Educational mismatch is defined as the lack of coherence between required and offered educational level for a given job (Allen \& Van der Velden, 2001). The incidence of educational mismatch is one of the elements used to estimate the effectiveness of qualifications. Educational mismatch arises in the form of over education (i.e. workers have more education than is required for their jobs) or under education (i.e. workers have less education than is required for their jobs). Vertical mismatch of education (mismatch of level of education and job) is not the only form of educational mismatch. Another important form of mismatch is horizontal mismatch (i.e. mismatch of field of study and job).

The abilities, skills, attitudes and knowledge owned by workers, which is their qualification, may be lower or higher than those required in their jobs. When this takes place, the worker is said to be mismatched in qualification: underqualified, when his/her qualification is below that required in his/her job, and over-qualified, when that exceeds the requirement. Over-education/over-qualification is a relative phenomenon. A person over-educated/over-qualified in one job may not be in another job. Overeducated workers are defined as those whose educational attainments exceed to the requirements of education in a particular occupation. Women have more probability of being over educated as compared to men (Richard, 2011). The people having disabilities have less probability of being over educated (Malo, 2005).

Graduates who do not possess the knowledge equivalent to their qualification level suffer from educational mismatch as well as from over education. This is due to a gap between required and acquired knowledge. Moreover, knowledge plays a crucial role in the development of the policies and plans. Deficit in the knowledge causes failure of the economy to develop the appropriate policies for the growth of the country. Over education is considered as a basic determinant of educational mismatch. In earlier studies educational mismatch is perceived as temporary phenomena (Quintano, Castellano and Agostino, 2008). The empirical text in various developed regions has mainly focused the overeducation' which range from 10 percent to 40 percent in various developed countries (Malo, 2005). The phenomenon of over-education is generally assessed by comparing the education acquired by each worker with that required by his/her current job, and, as a result, workers are typically classified into overeducated, undereducated, and adequately educated.

Knowledge is the first requirement for getting any job. The students who have sufficient knowledge of their field of study have more probability of employability. If the students do not possess knowledge equivalent to their degree then they are not considered eligible for that job. This is the reason behind over-education. Students who are suffering from 
the knowledge deficit then are supposed to work at lower position while their fellows enjoy the high level of employment. There is a general consensus that economics graduates are weak in the area of applied problem solving with questions raised about the teaching and learning methods applied at undergraduate level. It is generally acknowledged that graduates came with limited experience in communication styles (Doherty, 2007). It is generally observed that many graduates even unable to write a letter for the job when they are asked to do that.

Graduates have more job opportunities as compared to undergraduates in economics. The increasing differentiation of labor due to the diffusion of new technologies and new modes of production organization (Handel, 2003), the switch from capital-intensive to knowledge-intensive economies (Zafar, 1999), and the new international division of labor (Chernoff, 2010) all push towards a differentiation in the demand for skills, hence to the growing dissatisfaction with mono-dimensional measures of mismatch, such as years of education. Economists have argued that acquired knowledge and skills are not equally productive (Quintano et al, 2008). Educational mismatch corresponds to a mismatch between acquired and required knowledge and skills (Allen and Velden, 2001).]

Different determinants of knowledge of economics can be used as the indicators of knowledge and educational mismatch e.g. interconnection between economic and other phenomena, economic policies, knowledge of opportunity cost, marginal considerations, impact of expectations and surprises etc. Knowledge of macro economics as well as of micro economics is considered obligatory for the graduates in economics. Macro is vital for many here; macro awareness and understanding is vital for rounded economists (Doherty, 2007).

There are different reasons behind educational mismatch. Educational mismatch might be happened because of the inefficiency of educational institutions and inefficiency of the educational curricula. References also play an important role in getting a job. Educational mismatch happens due to weak family background. Some reasons behind educational mismatch are gender inequality, disability, socio-economic status, parents' education, contacts, deficiency in skills and knowledge etc. Educational mismatch can be studied in variety of fields and disciplines. This is particularly for graduates in economics, since this degree is considered 'Strong' because it offers a wide choice of alternatives and has high external effectiveness. Students of economics expect high returns in terms of employment and educational mismatch. Economics is a discipline that has high weight in the labor market of world as well as of Pakistan. The curriculum being followed in the Pakistan is not successful to equip the students with the basic concepts those are requirement of employers.

The subject has a broad focus but still graduates in economics are facing the difficulties in getting the jobs that are matching with their qualification. Most of the employers reports that graduates in economics do not possess good communication skills. Students are unable to apply their knowledge when they are offered to work in the field. There are different factors that are responsible for educational mismatch in economics. Graduates in economics are also facing the problem of educational mismatch. There are evidences on the fact that the curricula on economics is not working. Based on the reasons, the study was conducted on educational mismatch in knowledge that graduates in economics posses and that market requires in Pakistan. The main focus of this study is the identification of the major causes of educational mismatch. Phenomenon of educational mismatch has been studying in terms of over-education, qualification mismatch, job mismatch, content mismatch etc.

Objectives of the study are to identify mismatch in knowledge that graduates in economics possess and to explore causes of educational mismatch in terms of knowledge that graduates possess and that market requires.

Following research questions were formulated:

1. Does educational mismatch exist in knowledge among economics graduates?

2. If yes, then why does it exist?

3. Is there any difference between perception of students and employers about knowledge possession?

4. Is there any difference between percentage of marks demanded by employers and percentage of marks possessed by students?

5. Is there significant difference between knowledge possessed by males and females?

6. Is there significant difference between knowledge possessed by high and low achievers?

7. Is there significant difference between knowledge possessed by part and full-time students?

\section{Population, Sample \& Sampling}

All the graduates in economics of private colleges, public colleges and University of Sargodha in Sargodha city were the target population of this study. Due to the time constraint students studying in department of economics of one of the public sector universities in Punjab, Pakistan were selected as the accessible population of the study. Similarly, the 
available employers from one of the districts of Punjab were accessible population.

Out of all the students studying in department of economics, 200 students studying at BS level were selected as the sample who believed to be the true representative of the given population and also had the characteristics relevant to the research problem. Furthermore, sample was categorized into full time and part time students, male and female students, high achievers and low achievers. So that 133 full time and 67 part time students, 105 female students and 95 male students, 105 high achievers and 95 low achievers were selected for the data collection. Out of all the employers working in the city, 32 employers were selected as the sample of the study who believed to be the true representative of all the employers. Due to the time constraint and limited availability of the participants of the study non-random convenient sampling was used.

Two questionnaires were used for collecting data. One questionnaire was used to collect data from students and the other questionnaire was used to collect data from the employers. Depending upon the nature of the problem, questionnaire survey was used. Gender, achievement level, situation of the students (full time/part time), family background, work experience, knowledge are main causes of educational mismatch as highlighted by different studies. Indicators used in the survey conducted by University of the West of England, Bristol, 2007, were used to measure the knowledge of the graduates of economics. And more indicators were included after consultation with teachers and employers. Finally 15 indicators of knowledge were selected for the study. Two different questionnaires were used to collect the data (students' questionnaire was found reliable with reliability coefficient Cronbach Alpha 0.914, employers' questionnaire was found reliable with reliability coefficient Cronbach Alpha 0.928) were used. A sample of 200 students was surveyed through questionnaire. On the other side sample of 32 employers was also surveyed through questionnaire. This study involved cross-sectional survey design because data was collected from the students of department of economics and employers at the same point in time. The nature of the study was quantitative form and it was survey type study. Two questionnaires were used for the collection of the data. Students studying in the final semester at BS level in department of economics were visited and they were provided the questionnaire to tick the appropriate option. Likewise employers were visited and they were also provided the questionnaire to tick the appropriate option on a rating scale using five different columns. Weights (ranging from 1 to 5 i.e. 1- not at all, 2- to some extent, 3- to an adequate extent, 4- to a high extent and 5- to a very high extent) were assigned.

\section{Data Analysis}

Data was analyzed through the SPSS. Independent sample t-test and percentage of responses of employers and students were used to test the hypotheses and analyze the data.

Table 1: Students' percentage of marks and percentage of marks demanded by employers

\begin{tabular}{|c|c|c|}
\hline Percentage of marks & Students' achievement level & Achievement level demanded by employers \\
\hline above 40 & 0.5 & 3.3 \\
\hline above 50 & 3.5 & 20.0 \\
\hline above 60 & 43.5 & 60.0 \\
\hline above 70 & 52.5 & 16.7 \\
\hline
\end{tabular}

Table 1 shows that students' achievement level and achievement level demanded by employers for job. Achievement level of most of the students is above $70 \%$ and the most demanded achievement level by employers is above $60 \%$. Results show that achievement level of students is more than the achievement level demanded by employers.

Table 2: Knowledge possessed by students and knowledge possession of students according to employers

\begin{tabular}{|l|c|c|}
\hline \multicolumn{1}{|c|}{ Indicators of knowledge } & \% of students' perception & \% of employers' perception \\
\hline interconnections between economic and other phenomena & 55.1 & 53.9 \\
\hline economic policies & 63.7 & 58.0 \\
\hline marginal considerations & 59.4 & 55.3 \\
\hline impact of expectations and surprises & 56.6 & 53.3 \\
\hline interdependency of markets and economic welfare & 66.1 & 48.6 \\
\hline macroeconomic variables & 70.1 & 57.3 \\
\hline microeconomics of decision and constrained choice & 66.1 & 57.4 \\
\hline
\end{tabular}




\begin{tabular}{|l|l|l|}
\hline Social cost and benefits & 65.9 & 59.3 \\
\hline incentives & 64.7 & 62.7 \\
\hline inflation and deflation & 73.0 & 55.9 \\
\hline equilibrium, disequilibrium and stability & 70.6 & 57.3 \\
\hline opportunity Cost & 68.8 & 52.7 \\
\hline marketing & 65.7 & 69.3 \\
\hline financial resources and human resources & 67.3 & 60.7 \\
\hline international trade and exchange rate & 68.7 & 50.0 \\
\hline
\end{tabular}

Table 2 shows students' self perception about their knowledge possession and employers' perception about their knowledge possession. According to students, interconnection between economic and other phenomena, marginal considerations, impact of expectations and surprises, incentives and marketing are the deficient areas in knowledge. According to employers, students are deficient in their knowledge about interconnection between economic and other phenomena, marginal considerations, impact of expectations and surprises, interdependency of markets and economic welfare, inflation and deflation, opportunity cost and international trade. The results shows that interconnection between economic and other phenomena, marginal considerations and impact of expectations and surprises are most deficient areas of knowledge possessed by students.

Table 3: Knowledge possessed by males and knowledge possessed by females

\begin{tabular}{|c|c|c|c|c|c|c|c|}
\hline Serial \# & dependent variable & gender & $\mathrm{N}$ & Mean & Standard deviation & $\mathrm{t}$ & Sig.(2-tailed) \\
\cline { 1 - 5 } 1 & \multirow{2}{*}{ Knowledge possession } & male & 95 & 47.75 & 9.56 & \multirow{2}{*}{-2.253} & \multirow{2}{*}{0.025} \\
\cline { 3 - 7 } & & female & 105 & 51.04 & 10.94 & \\
\hline
\end{tabular}

The independent sample $t$ test as shown in the table 3 shows that there is significant difference in knowledge possessed by male and female students of economics $(\mathrm{t}=-2.25$, Sig. $=0.025$, Mean Male $=47.75$, Mean Female $=51.04)$. Female students of economics have more knowledge as compared to male economics students.

Table 4: Knowledge possessed by high achievers and knowledge possessed by low achievers

\begin{tabular}{|c|c|c|c|c|c|c|c|}
\hline Serial \# & dependent variable & achievement & $\mathrm{N}$ & Mean & Standard deviation & $\mathrm{t}$ & Sig.(2-tailed) \\
\cline { 1 - 6 } 1 & \multirow{2}{*}{ Knowledge } & Low achievers & 95 & 47.74 & 10.10 & \multirow{2}{*}{-2.267} & \multirow{2}{*}{.024} \\
\cline { 4 - 8 } & & High achievers & 105 & 51.05 & 10.49 & & \\
\hline
\end{tabular}

The independent sample $t$ test as shown in the table 4 shows that there is significant difference in knowledge possessed by high achievers and low achievers ( $\mathrm{t}=-2.26$, Sig. $=0.024$, Mean Low achievers $=47.74$, Mean High achievers $=51.05)$. High achievers possess more knowledge as compared to low achievers.

Table 5: Knowledge possessed by full time students and knowledge possessed by part time students

\begin{tabular}{|c|c|c|c|c|c|c|c|}
\hline Serial \# & dependent variable & Situation & $\mathrm{N}$ & Mean & Standard deviation & $\mathrm{t}$ & Sig.(2-tailed) \\
\cline { 1 - 5 } 1 & \multirow{2}{*}{ Knowledge } & Full time & 133 & 49.41 & 11.31 & \multirow{2}{*}{0.136} & \multirow{2}{*}{.892} \\
\cline { 4 - 7 } & & Part time & 67 & 49.62 & 8.44 & \\
\hline
\end{tabular}

The independent sample $t$ test as shown in the table 4.99 shows that there is no significant difference in knowledge possessed by full time students and part time students $(\mathrm{t}=-0.136$, Sig. $=0.892$, Mean Full time students $=49.41$, Mean Part time students=49.62). Part time and full time students have equal knowledge possession.

\section{Findings}

1. The significant difference between knowledge possessed by males and knowledge possessed by female students of economics was found to be -2.25 at 0.05 significance levels of confidence. So there exists significant difference between knowledge possessed by males and females. The mean of knowledge possessed by female students i.e. 51.04 is greater than mean of knowledge possessed by male students i.e. 
47.75 .

2. The significant difference between knowledge possessed by high achievers and knowledge possessed by low achievers of economics was found to be -2.26 at 0.05 significance levels of confidence. So there exists significant difference between knowledge possessed by high and low achievers. The mean of high achievers' knowledge 51.05 is greater than mean of low achievers i.e. 47.74 .

3. The significant difference between knowledge possessed by full time students and knowledge possessed by part time students of economics was found to be -0.136 at 0.05 significance levels of confidence. So there exists no significant difference between knowledge possessed by full time and part time students. The mean of knowledge possessed by full time students is 49.41 and the mean of knowledge possessed by part time students is also 49.41 .

\section{Conclusion}

Interconnection between economic and other phenomena, marginal considerations, impact of expectations and surprises, incentives and marketing are the deficient areas in knowledge according to students. While students are deficient in their knowledge about interconnection between economic and other phenomena, marginal considerations, impact of expectations and surprises, interdependency of markets and economic welfare, inflation and deflation, opportunity cost and international trade according to employers. It was found that interconnection between economic and other phenomena, marginal considerations and impact of expectations and surprises are most deficient areas of knowledge possessed by students. As a result, this deficiency in knowledge can cause educational mismatch. It was concluded that students' achievement level is more than the achievement level required for a job. It was concluded that females have more knowledge as compared to males, so they suffer more from educational mismatch, as they have surplus in knowledge. Furthermore, high achievers have more knowledge as compared to low achievers. So high achievers suffer from surplus in knowledge and low achievers suffer from deficit in knowledge. As a result deficit and surplus in knowledge increases the probability of educational mismatch. Findings showed that part time and full time students have no difference in knowledge. So the situation of the student (part time/full time) doesn't cause educational mismatch. Hence, it is concluded that difference in achievement level and gender can cause educational mismatch.

\section{Recommendations}

As it is evident from the results of the study there exists educational mismatch among the students of economics, so keeping in view the findings, conclusion following are recommendations for further studies:

1. Different variables are needed to examine the educational mismatch.

2. Studies on phenomena of educational mismatch should be conducted on different educational level.

3. Due to time and other constraints employers requirements were not addressed, in further studies requirements of the employers should be identified.

4. The study was limited to students of economics, it is suggested that in future other disciplines should be included in the research study.

5. Various methods and approaches can be applied to the same study for future research.

6. It is suggested that studies on different causes of educational mismatch e.g. disability, geographical immobility; gender differences, wage differences and achievement level should be conducted.

\section{References}

Adams., \& Smart. (2008). Education and Lifelong Learning, The Scottish Government

Allen, J.,\& Valden, V. V. (2001). Educational mismatches versus skill mismatches: effect on wages, job satisfaction and on-the-job search, Oxford Economics Paper, 1(3), 434-452, Oxford University Press.

Chernoff, V.,\& Boudarbat, B. (2010). The Determinants of Education-Job Match among Canadian University Graduates, CIRANO

Chiswic, B. R., \& Miller, P. W. (2009). Educational Mismatch: Are High-Skilled Immigrants Really Working at High-Skilled Jobs and the Price They Pay If They Aren't? , Discussion Paper No. 4280

Desjardins, R., \& Rubenson, R. (2011). An Analysis of Skill Mismatch Using Direct Measures of Skills, OECD Education Working Papers, No. 63, OECD Publishing. http://dx.doi.org/10.1787/5kg3nh9h52g5-en

Doherty, R.O., Street, D., \& Webber, C. (2007). The Skills and Knowledge of the Graduate Economist, University of the West of England, Bristol

Groot, W., \& Maasen (2000). Overeducation in the labor market: a Meta- Analysis Economic of Education Review, 1(19), 149-158. 
Handel, M. J. (2003). Complex Picture of Information Technology and Employment Emerges, SRI Project Number P10168

Lopez, M. R., \& Murillo, I. P. (2009). Educational attainments, educational mismatch and gender wage differentials: an application to the Spanish case, FEDER

Malo, M. A. (2005). Educational Mismatch and Labor Mobility of People with Disabilities: A Spanish Case, Blazquaz and Malo/Revista de Economia Laboral, 5(2), 31-55.

Miller, N. (2012). Alternative Forms of Formative and Summative Assessment, University of York

Quintano, C., Castellano,R., \& Agostino, A,D. (2008). Graduates in economics and educational mismatch: the case study of the University of Naples 'Parthenope',Doi: 10.1080/13639080802214118, Journal of Education and Work, 8(3), 249-271

Zafar, N. M. (1999). Do Private Schools Produce More Productive Workers, The Pakistan Development Review, 937-954. 